\title{
ASYNCHRONOUS LEARNING NETWORKS: POLICY IMPLICATIONS FOR MINORITY SERVING INSTITUTIONS AND FOR LEADERS ADDRESSING NEEDS OF MINORITY LEARNERS
}

\author{
Dr. Janet K. Poley \\ President/CEO \\ American Distance Education Consortium
}

\begin{abstract}
"What can happen is a decline in our standard of living, if more Americans are not empowered and educated to participate in a world where all the knowledge centers are being connected. We have within our society all the ingredients for American individuals to thrive in this world, but if we squander those ingredients, we will stagnate.”
\end{abstract}

Thomas L. Friedman

\begin{abstract}
For minority serving institutions, policies that support learners call for decisions about equity, quality, cost, impact on national economic performance and international global relationships.
\end{abstract}

\section{KEYWORDS}

National and State Policies, MSIs and Minority Learners, Multicultural Organizational Framework

\section{INTRODUCTION}

Changing U.S. demographics and globalization factors of the type described by Thomas Friedman in The World Is Flat (rapidly expanding technology infrastructure, politics, innovation) [1] are creating the environment within which policies in this country and around the world are and will be developed well into the first 25 years of the century. This paper is focused on the Minority Serving Institutions including formally designated MSIs as well as other public and private institutions desiring to provide online learning opportunities for diverse audiences. Policy choices involve decisions about equity, quality, cost, impact on national economic performance and international global relationships.

College attendance in the United States has grown rapidly over the past 40 years with ever increasing student aspirations. Ninety percent of today's high school students hope to attend college [2]. As attendance rates have risen, so has the diversity of the student body. Minorities now comprise twentyeight percent of college students although some groups are still underrepresented. Fifty-eight percent of bachelor's degree recipients attend two or more colleges. Twenty-eight percent of undergraduates attend part-time and seventy-three percent are non-traditional students. By 2015, one to two million additional young adults will seek access to college, many from low income and minority families. (It should be noted in this introduction that minority and low income, while sometimes correlated, are not the same. Also, minority learners come from many socio-economic backgrounds and circumstances and are found distributed across the performance curve.) Today the national expectation standard is no longer high school education, but college education for all. Research confirms that in all settings whether urban, rural 
Asynchronous Learning Networks: Policy Implications for Minority Serving Institutions and for Leaders Addressing Needs of Minority Learners

or suburban, persistence, good teaching and an environment of great expectations elicit better performance from all students.

\section{II. “WHEN MUCH IS EXPECTED MUCH IS ACHIEVED”}

Minority Serving Institutions (MSIs) currently educate approximately 35\% of the U.S. minority population. These institutions are a critically important doorway to higher education. They are less than $3 \%$ of the nation's two and four-year institutions. Historically Black Colleges and Universities produce $28 \%$ of all bachelor's degrees, $15 \%$ of all master's degrees and $17 \%$ of all first professional degrees earned by African Americans.

Some key historical factors that have led to the U.S. reaching near universal college attendance:

- Between 1960 and 2001 college enrollments expanded from 4.1 million to 14.8 million.

- During the same time period there was a 57\% population increase and the baby boomers came of age.

- State and university systems grew adding 743 community colleges.

- $\quad$ The GI Bill educated 6.3 million veterans.

- The Economic Opportunity Act of 1964 established Work-Study.

- There was a three-fold increase in federal support for higher education (loans, grants, teacher training, infrastructure).

- The focus on women's rights and Title IX changed the gender balance.

- New opportunities in distance education and a job market requiring higher levels of education to use technology and information became increasingly diverse toward college education and lifelong learning.

\section{WHAT IS A MINORITY SERVING INSTITUTION?}

While nearly all public and private higher education institutions serve minority populations to a greater or lesser degree, The Higher Education Act of 1965 gave special recognition to some postsecondary schools that serve a high percentage of minority students as Minority Serving Institutions (MSIs).

\section{HISTORICALLY BLACK COLLEGES AND UNIVERSITIES (HBCUS)}

Today there are 105 Historically Black Colleges and Universities (HBCUs). Forty are public four-year; 49 are private four-year; 11 are two-year public and 5 are two-year private institutions. The majority of the HBCUs are in the south: Alabama (15); Arkansas (4); District of Columbia (2); Delaware (1); Florida (4); Georgia (10); Kentucky (1); Louisiana (6); Maryland (4); Mississippi (8); Missouri (2); North Carolina (11); Ohio (2); Pennsylvania (2); South Carolina (8); Tennessee (6); Texas (9); Virginia (5); West Virginia (2); U.S. Virgin Islands (1). The 1890 Morrill Act created black land-grant colleges and universities and today there are 17 public land grants including Tuskegee, a private state-related institution. The University of the District of Columbia (UDC) and the University of the Virgin Islands were established under the 1862 Morrill Act. UDC, along with Howard University, are two of the largest MSIs. Forty percent of all students in four-year HBCUs are in black land grants. Eight of the black land grants offer Ph.D.s and Florida A\&M, Tennessee State and Southern University (LA) are three of the 
top five black institutions producing African American Ph.D.s. It is currently estimated that HBCUs serve approximately 285,000 students (Sloan Survey). The HBCUs collaborate in a number of ways including work through the National Association of State Universities and Land Grant Colleges (NASULGC) and NAFEO. Increasingly, all MSIs are working together under an umbrella of diversity.

\section{TRIBAL COLLEGES AND UNIVERSITIES (TCUS)}

Today there are thirty-three Tribal Colleges and Universities that are included in the White House Initiative on TCUs. All of these institutions are designated as 1994 land-grant institutions receiving support from the U.S. Department of Agriculture and the Bureau of Indian Affairs. They are located in ten states: Arizona (2); Kansas (1); Michigan (3); Minnesota (4); Montana (7); Nebraska (2); New Mexico (3); North Dakota (5); South Dakota (3); Washington State (1); Wisconsin (2). (D.Q. College in California was recently closed.) One hundred percent of these institutions are public and they currently serve approximately 30,000 students (2004). Tribal colleges share missions of preservation of language and culture and are primarily chartered by tribal governments and receive their base funding from congressional legislation never fully funded. They have never received the authorized level and are generally severely under funded. TCUs play a major role in local communities [3]. Most of these institutions are two-year colleges serving an average of 467 students, many of whom are single, reservation-based women with children.

Technological advances are only slowly evolving on rural reservations and a large digital divide continues. A recent FCC report noted that reservation based Indian populations and K-12 schools on these reservations frequently are not connected to the Internet, telephone penetration is much lower than the rest of the country [4] and while the TCUs generally have well-equipped computer networked laboratory facilities, the divide perpetuates the isolation of tribes and serves as a deterrent to needed educational economic development. The work of two National Science Foundation supported projects, one managed by EDUCAUSE and one by ADEC, found that there are a variety of barriers slowing the development of technology and the opportunities for distance education on reservations: 1) distrust of new technologies; 2) remote geographic location; 3) weak tribal economies; 4) lack of government policies targeted to improving technological infrastructure and online teaching and learning capacity; 5) lack of property rights for American Indian intellectual property shared on the Internet.

Generally, the educational attainment level of American Indians has been lower than any other ethnic or racial minority in the U.S. The American Indian Higher Education Consortium (AIHEC) has historically provided national leadership to advance the work of these colleges. Eighty-five percent of students attending tribal colleges are American Indian/Alaska Native [5]. Approximately 8\% of all American Indian/Alaska Native students are enrolled in tribal colleges. The students attending TCUs are more likely to be from lower socio-economic levels than students enrolled in other types of postsecondary institutions. Eighty-five percent of tribal college students have incomes below the poverty level for a family of four. The percent of tribal college students receiving Pell grant funds (60\%) is more than double that of students attending non-minority serving institutions (24\%)[5].

Tribal colleges are beginning to see distance education as an opportunity, and are developing and implementing online distance education courses and, in a few cases, degree programs for their students. Of all MSIs, Tribal Colleges offer the fewest online courses[5]. Some tribal leaders may not see the opportunities that might be possible if TCUs were to partner with other TCUs and the broader set of landgrant institutions in the country. Administration and faculty retention is difficult, particularly at the more remote institutions, and ADEC is currently working with a number of these colleges to help determine how they might both offer and take academically and culturally appropriate educational programs. 
Asynchronous Learning Networks: Policy Implications for Minority Serving Institutions and for Leaders Addressing Needs of Minority Learners

\section{HISPANIC SERVING INSTITUTIONS (HSIS)}

There are currently 335 HSIs including 46 public, 23 private nonprofit and 32 private for-profit. Federal statute defines HSIs as institutions that have at least a 25\% Hispanic undergraduate (FTE) enrollment, with at least $50 \%$ of its Hispanic students coming from low-income background and being first generation in their family to attend college and an additional 25\% being low income or first generation. They are eligible for Title $\mathrm{V}$ grants from the Department of Education. Various organizations count Hispanic/Latino enrollment numbers differently, but by all definitions urban areas are the primary locations of attraction for these students who seek community with other Hispanics, employment opportunities and low-cost higher education institutions [6].

At least $68 \%$ of HSIs are community colleges which educate almost half of all Latinos enrolled in higher education. HSIs represent $6 \%$ of all higher education and enroll $21.2 \%$ of students from other racial and ethnic groups, i.e. these campuses tend to be quite diverse, expanding beyond the Latino population and embracing other groups. Hispanics/Latinos represent 35 million (12.5\%) of the U.S. population and are expected to grow to 61 million and represent $18 \%$ of the population by 2025 . They are among the least educated in the American population, but because of large numbers and relatively youthful demographics, they are making a significant impact at all educational levels. While there are strong reasons to continue to focus attention on Latino education using all delivery modes, the Pew Hispanic Center found in 2002 that $73 \%$ of U.S. born Latinos finished high school, $40 \%$ obtained some college education and about $14 \%$ earned a four-year degree [6].

Fourteen states have 82.4\% of HSIs and 59 are in Puerto Rico. Most are located around the perimeter of the country but several are found in the middle of the country. The states with HSIs are Arizona (19); California (109); Colorado (7); Florida (19); Illinois (11); Massachusetts (2); New Jersey (5); New Mexico (25); New York (21); Oklahoma (1); Oregon (1); Pennsylvania (1); Texas (54); and Washington (1) [6].

\section{FOR-PROFIT PROPRIETARIES INCREASINGLY A FACTOR IN MINORITY ONLINE EDUCATION}

For-profit proprietary institutions are rapidly stepping in and targeting higher education programs to low income (other minority students) eligible for financial aid. Most of these programs rely on regular higher education institutions for online program design and delivery through use of consultants for shaping course and adjunct faculty. Many of these organizations are serving minority students in face-to-face environments principally in urban centers as well as online. Costs of these for-profit programs are generally two to three times as expensive to the student as public institutionally offered higher education in any type of delivery mode. However, in terms of access, students are getting served who were not previously attracted to more traditional institutions for various reasons. A major minus is that for profits by definition are looking to make profits and fewer students can potentially be served from the federal pool of scholarship assistance for needy students if costs are two to three times higher than other alternatives (i.e. the federal government is paying more for fewer educations). If these students were fully paying for their own programs, there would be no policy question because it would simply be a marketplace decision. Aggregated data does not seem to exist as to the degree students are working to pay part of their higher priced distance education course and their supplementing it with a Pell grant of $\$ 4000$, as an example. 


\section{USE OF ONLINE DISTANCE EDUCATION/ALN AT MSIS}

\section{A. Government Accounting Office (GAO) - 2004}

While there is considerable variation among these institutions, the following appear to be patterns:

- All MSIs offer at least one distance education course (generally online) at the same rate as all other higher education institutions.

- Larger MSIs, just as is the case for all higher education institutions, offer more online courses/programs than small institutions.

- $\quad$ Public MSIs offer more than private MSIs.

MSIs generally offer courses to:

- Improve access for students living away from campus, and

- Provide convenience to adult, employed learners.

All MSIs identify 1) limitations in federal funding policies for infrastructure; 2) student scholarships; and 3) inadequately and ill-prepared faculty as the biggest challenges they face in implementing larger programs in online distance education.

GAO concluded that progress could best be made by collecting more complete data on technology implementations at MSIs and by developing baseline measures on technology enabled education focusing on student outcomes. Institutional benchmarks and measures need to be developed to demonstrate capability to offer quality programs online, as well as administer programs from other locations into a face-to-face environment.

\section{B. The House Education and Workforce Committee (http://edworkforce.house.gov)}

The House Republicans have been arguing that college costs are too high, jeopardizing the ability of low and middle income students to attend college [7]. While on a percentage basis, college tuition costs have risen for both public and private institutions, generally speaking, community colleges and public fouryear institutions still have substantially lower tuition rates than private institutions. Part of this difference is due to state support to institutions of higher education, particularly in setting tuition lower for instate students to attend these institutions.

There is bipartisan support for eliminating access barriers to higher education generally and to expand opportunities for students by removing barriers and adopting innovative solutions such as online distance learning through the use of advanced technology.

Basic issues of equity and fairness, with respect to various classes of learners and providers, overlay the policy environment. Some of the issues being debated include:

- The 90/10 rule-whether to repeal the requirement that proprietary institutions must derive at least $10 \%$ of funds from non-federal sources.

- The 50\% rule-whether to repeal or not - the current Department of Education demonstration project includes 24 institutions and allows waivers to other institutions that apply. This rule limits the number of students that may be enrolled in distance education and the number of courses that can be offered by distance education. 
- Current definition of HIS-more institutions argue that they should be allowed to participate as the U.S. Hispanic population increases at many institutions.

- Rules applying to federal grant administration - there are variations in MSI footing with respect to other institutions - matching requirements are a particularly sticky issue given that MSIs typically receive a very large share of their funds from the federal government. The policy that you cannot match federal dollars with federal dollars makes it particularly difficult for small MSIs (especially the Tribal Colleges and smaller HBCU land grants) to participate in collaborative projects where they would be expected to provide some match. Institutions in Alabama, Louisiana and Mississippi have been working together to convince state legislatures that they should be considered for state funds which could then be used to attract federal funding. This constraint frequently limits MSI participation in collaborative grants related to information technology infrastructure and distance education. Some federal agencies including NSF and the U.S. Department of Agriculture's Cooperative State Research and Education Service have reduced or eliminated their match requirements for this reason.

- Targeting new federal funding for MSIs with a focus on developing and improving facilities for Internet use and other distance learning capacity requirements. For two years in a row the U.S. Senate has passed unanimously a bill that would authorize millions of dollars for MSIs in this area. To date a comparable bill has not passed the House of Representatives.

- Student financial assistance — complexity of current system — the formula for determining who is eligible and the degree to which student earned income affects the amount of student assistance available to undergraduate students is unclear.

\section{The U.S. Department of Education}

The U.S. Department of Education has been encouraging development of an environment that will expand access to distance education programs more broadly. Some results from the demonstration program mentioned above have been analyzed. This demonstration program included nine for-profit institutions, five publicly traded, seven private nonprofit, four public universities, one public system and three consortia.

The participating institutions have seen heavy increases in their online enrollments (deemed a success in terms of access), and the policy question remains with respect to provisions of the Higher Education Act as to whether elimination of the $90 / 10$ and $50 \%$ rules would further increase access to "quality distance education". Data is currently available from eight institutions from the original group covering six years of implementation. Kaplan, North Dakota State University System, University of Maryland University College (UMUC) and Southern Christian University had 7,930 distance education students in 1998-99 when the project began. Together they now have 63,350 distance education students (2003-2004).

Regis University, the University of Phoenix and Walden University grew from 45,997 in 2000-2001 to 223,404 online in 2003-2004.

Five of the seven largest institutions in the program have more than half their students qualifying for federal financial aid: American InterContinental University (76\%); Capella (68\%); Kaplan (79\%); Phoenix (68\%) and Walden (56\%).

The major issue identified with the for-profits is cost, although quality questions have not been resolved across all accrediting agencies with respect to common standards for judging outcomes. The area of 
learning outcome measures for distance education and face-to-face is somewhat of a "swamp" trying to compare baskets of apples and oranges. Tuition rates at proprietary institutions are higher than at community colleges and public four-year institutions, but sometimes less expensive than four-year private colleges, i.e. a student pays $\$ 8100$ for a full time load at Strayer University compared with approximately $\$ 1500$ at a community college or approximately $\$ 4000$ per semester for instate tuition at a public fouryear institution.

Increasingly public four-year institutions are setting tuition for face-to-face instate tuition and online tuition at comparable rates. Often distance education rates are set at instate tuition level for all online students irrespective of location. Some technology fees are increasingly applied in both face-to-face and online environments.

Capella University and Southern Christian University reported nearly one-third of their students are members of minority groups, and UMUC reported that 53\% of its undergraduates in distance education are minorities and one-third are African American.

In both face-to-face and online proprietary institutions including DeVry, entrance requirements - barriers to access - such as ACT and SAT are eliminated. Forty-five percent of DeVry's students are minorities and most are first-generation college students.

\section{THE STUDENT PERSPECTIVE-BETTER SERVING MINORITY STUDENTS THROUGH ALN}

An increasing number of higher-education students are and will be taking all or part of their educational programs online. Collection of better baseline data and more sophisticated interpretation of the meaning of this evolution with respect to student outcomes and changes for MSIs as well as learners from population groups historically disadvantaged must be studied from a policy perspective.

Minority populations are increasingly choosing to further their education in the online environment (particularly more mature learners who are working and job focused) especially when they have incomes high enough to afford tuition and/or federal assistance to pay all or part of the cost. Two of the major factors identified in this change are: the convenience of online learning; and the decreased difficulty of gaining enrollment, particularly proprietary institutions that have eliminated tests as a barrier to access.

UMUC appears to be a particularly fruitful model for policy study for a possible "best of all worlds effect." UMUC's unique institutional history, its placement within the public University of Maryland System, the scope and scale at which it is able to operate and its seeming ability to attract minority students in large numbers to a reasonably priced large set of offerings is unusual. Their long-term work with diverse military populations around the world may have contributed to their seeming success in attracting minority students.

Some of the additional student focused areas that should be studied and considered in modifying existing state and federal policies and funding streams include:

- The unique role of HBCUs and Tribal Colleges in getting learners started - they serve a large number of minorities. The HBCUs have been particularly successful in the face-to-face environment, yet it is an open question as to whether some of the success factors can be translated into online delivery. 
- Recent studies are showing a large increase in students who attend at least two institutions of higher education on the way to a bachelor's degree reflecting explicitly planned transitions from community colleges to four-year institution (two plus two programs) and the larger availability of online course offerings.

- Co-enrollments (sometimes called dual enrollments) are also increasing as larger numbers of students are enrolled in two or more institutions at the same time.

- Students report more difficulty in changing from one institution to another in the real world than in the virtual world—with "cultural factors" playing a large role in the face-to-face environment. Interestingly, students report little or no difficulty today in credit transfer from one institution to another. This problem seems to have largely been solved. All students-minority or not-are shopping for higher education from a variety of vendors. Price, convenience and quality are key factors with respect to selection-including whether the learner must pay for the offering or have subsidized tuition from federal funds or other sources.

- Completion and retention rates need further study with particular attention to minority populations when multiple institutions of higher education are involved in the program. Time to degree is also important to study, but without prejudice as to how long it "should" take for an adult to obtain a degree. Given the older working adult population, consideration should be given to fact that fewer and fewer learners in higher education are of the traditional age, particularly with respect to minority populations, including new immigrants.

- Full participation of minority administrators and faculty with experiences at MSIs as well as other types of institutions should be involved in the accreditation and policy-making process.

- Different states and regions have opportunities and challenges with respect to orchestrating congruence among various public institutions of higher education, including the MSIs - the south - toward the east has the majority of HBCUs, the west and southwest and increasingly the middle of the country have more TCUs and HSIs. These regional differences must be recognized in state and regional policy decisions, not simply at the federal level.

- Policy decisions about support for building MSI capacity for online distance education should not simply focus on technology and first-tier access questions, but rather focus much more heavily on the faculty teaching and learning components and quality student support services. It is clear from some of the success at the undergraduate level achieved by MSIs, particularly the HBCUs, there is learning that may be translated into the online world.

- Increasingly, MSIs are joining together for policy advocacy purposes-The Alliance for Equity in Higher Education [8] includes the MSIs discussed in this paper and together they support:

1. Enactment of the "Digital and Wireless Network Technology Program Act", an effort to address the variety and scope of the nation's MSIs information technology needs.

2. The creation of new sections in the Higher Education Act (HEA) under Titles III and V that provide new funding for technology maintenance and enhancements at HBCUs, HSIs, and TCUs.

3. The creation of a new subpart under the Minority Science and Engineering Improvement Program (MSEIP) during the reauthorization of HEA to encourage improvements in the infrastructure and application of information technology at MSIs.

4. Increase access for MSIs to new and existing federal programs that assist in the development of science and technology at higher education institutions and provide MSIs with opportunity parity to participate in the latest technological advancements.

5. Ensure that MSIs can participate fully in the NSF proposed Advanced Cyberinfrastructure Program. 
Asynchronous Learning Networks: Policy Implications for Minority Serving Institutions and for Leaders Addressing Needs of Minority Learners

6. Develop new graduate level opportunities to enhance the capacity of MSIs to train future faculty and senior institutional leaders.

7. Continue and expand funding from the Department of Education for preparing teachers to teach using technology.

8. Create a Hispanic-Serving Institutions Program within NSF similar to the TCUP and the HBCU-UP to build the information technology capacity of HSIs in the fields of science, technology, engineering and mathematics (STEM).

9. Target specific state funds to MSIs for expanding information technology capacity.

10. Expand industry contributions to MSIs for information technology capacity and innovation.

- MSIs are increasingly seeking partnerships with a variety of educational institutions in the U.S. and around the world with particular attention to cultural, language and historical dimensions. National policy issues with respect to support for these activities are under consideration.

\section{CONCLUSION}

A large agenda of institutional and student focused issues are under discussion focused on national and state policies with respect to MSIs and minority learners, particularly those requiring federal funding assistance. Not simply in the online environment, but across higher education, questions are being addressed as to how to move from a more typical monocultural framework to a multicultural organizational framework. No higher education institution can afford to ignore the cultural traditions, norms and perspectives of all other racial and ethnic groups in the resolution of these issues. The U.S. has and will continue to benefit substantially from its diversity. Some of this is about full access, equality, justice, freedom, choice and inclusiveness. But as recognized by many players, this is a question of enlightened self-interest. High quality, accessible higher education-maintaining and enhancing our historical standards is absolutely key to the future of the country. We continue forward as a nation of immigrants and minorities - our future together is all that is certain.

\section{ABOUT THE AUTHOR}

Janet Poley is CEO and President of the American Distance Education Consortium (ADEC). She develops collaborative distance education initiatives and conducts research and education programs related to technology access and applications with more than 60 land-grant university members and international affiliates. In April 2002, she was inducted into the International Adult and Continuing Education Hall of Fame and serves on its Board of Directors. She received the Mildred B. and Charles A. Wedemeyer Award for Outstanding Practitioner in Distance Education in 2000. She currently serves as principal investigator on a \$5 million National Science Foundation grant for advanced networking and applications including work on distance education and digital libraries in China. She is a Co-PI on an NSF start-up program in Human Language Technology—a collaboration between U.S. and Moroccan institutions. She manages the USDA funded Agricultural Telecommunications Program; manages a cooperative agreement with the National Agricultural Library (NAL) of USDA and the Universidad de Concepcion (UDEC) in Chile; is the chair-elect of the NAL AgNIC Board of Directors; and has received several Sloan Foundation and U.S. Department of Commerce grants. She is a member of the Council for Academic Management for the eArmyU; serves on the Editorial Board for the American Journal of Distance Education and the Board of Advisors for The Growing Connection (TGC), FAO; is a liaison to the National Association of State Universities and Land Grant Colleges (NASULGC); was a member of the Penn State Advisory Board to the World Campus Initiative; was a member of the Great Plains Network Advisory Committee; and is a special member of the University of Maryland Eastern Shore Graduate Faculty. She is a professor in the College of Journalism and the Institute of Agricultural and 
Asynchronous Learning Networks: Policy Implications for Minority Serving Institutions and for Leaders Addressing Needs of Minority Learners

Natural Resources at the University of Nebraska-Lincoln.

Dr. Poley is the author of a number of journal articles, book chapters and presentations on information technology and distance learning and currently co-authoring a book titled "Building an Inclusive Future for Learning: A Practical Guide for Campuses and Communities”.

She has been involved in training, technical assistance, program design and evaluation in more than 25 countries in Asia, Africa and Europe. In 1994, she was recognized as one of the 100 outstanding information technology leaders in government, business and academia by Federal Computer Week. From 1988 to 1994, she was Director/Deputy Administrator for Communication, Information and Technology (CIT) of the Extension Service, U.S. Department of Agriculture (USDA). Prior to 1988, she held a number of positions in international development and training within USDA. She served as Program Manager for the USAID funded Training for Rural Development projects, living in Tanzania from 1980 to 1986. In recognition of her international contributions, Poley received the U.S. Congress' Excalibur Award and USDA's International Honor Award. She received the USDA Administrator's Award of Excellence in 1991 and the Secretary of Agriculture's Award for Workplace Diversity in 1992.

From 1966 to 1975, she was a faculty member at the University of Nebraska-Lincoln. She holds three degrees from the University of Nebraska-Lincoln, a Ph.D. in Education, M.S. in Nutrition and B.S. in Journalism and Home Economics.

She is married to Jeffrey M. Poley, an architect who also works at ADEC.

\section{REFERENCES}

1. Friedman, T. The World is Flat: A Brief History of the Twenty-First Century. New York: Farrar Straus \& Giroux, 2005.

2. http://www.greatexpectationsok.org/ (requires login), and Kirst, M. W. and A. Venezia. Undermining Student Aspirations: The frayed connections between $\mathrm{K}-12$ and postsecondary education set students up for failure. National CrossTalk 11(2): Spring 2003. http://www.highereducation.org/crosstalk/ct0203/voices0203-undermining.shtml.

3. Leading the Way to America's Future: A monograph about the launch and implementation of the Kellogg MSI Leadership Fellows Program, 2002-2004. IHEP, August 2004. http://www.ihep.org/assets/files/publications/g-l/LeadingTheWay.pdf.

4. Federal Communications Commission. Lands of Opportunity: Bringing Telecommunications Services to Rural Communities. October 2006. http://www.fcc.gov/indians/opportunity.pdf.

5. NCES. http://nces.ed.gov/pubs2005/nativetrends/ind_7_2.asp.

6. Community College Journal of Research and Practice, 28(3): March 2004.

7. U.S. House of Representatives Committee on Education and Labor: http://edworkforce.house.gov/.

8. Alliance for Equity in Higher Education: http://www.msi-alliance.org/. 